\title{
KENDALA PENEGAKAN HUKUM TERHADAP CYBER CRIME PADA MASA PANDEMI COVID-19
}

\author{
Yuwono Prianto ${ }^{1}$, Nabila Annisa Fuzain ${ }^{2}$, Afif Farhan ${ }^{3}$ \\ ${ }^{1}$ Fakultas Hukum Universitas Tarumanagara, Indonesia \\ Email : Yuwonop@fh.untar.ac.id \\ ${ }^{2}$ Fakultas Hukum Universitas Tarumanagara, Indonesia \\ Email : nabilannisafuzain@gmail.com \\ ${ }^{3}$ Fakultas Hukum Universitas Tarumanagara, Indonesia \\ Email : afiffarhan3002@gmail.com
}

\begin{abstract}
Digital activity during the pandemic is increasing this is because people are asked to stay at home doing all activities online, this makes people vulnerable to becoming victims of cyber crime. Cybercrime itself is a cyber crime by using a computer or computer network as a tool, or as a target, as well as the location of the crime, the absence of space and time limits makes it easier for cyber criminals to carry out their actions in the cyber world. The author's purpose in conducting this analysis is to discuss what are the obstacles in handling cybercrime cases during the Covid-19 pandemic and how to enforce the law for cybercrime perpetrators. This article is the result of normative legal research that focuses on the use of secondary data. Cyber crimes need special attention from law enforcement, both national and international. The perpetrators of cybercrime have not been fully prosecuted due to the weakness of the cyber legislation system in Indonesia and the limited number of experts to handle this case. Cyber law has not been clearly spelled out in the regulations governing the technical implementation. The perpetrators of cyber crime come from various countries, limited human resources and infrastructure are the main obstacles. It requires a strong commitment from the leadership, law enforcement institutions to improve the quality and quantity of human resources as well as to prepare an adequate budget for the procurement of facilities and infrastructure as well as to establish cooperation with higher education to accelerate the handling of existing limitations.
\end{abstract}

Keywords: cyber crime; law enforcement.

\begin{abstract}
ABSTRAK
Aktivitas digital pada masa pandemi semakin meningkat hal ini disebabkan masyarakat diminta untuk tetap di rumah melakukan semua kegiatan dilakukan secara daring, hal ini membuat masyarakat rawan menjadi korban kejahatan cyber. Cybercrime sendiri adalah kejahatan dunia maya dengan menggunakan komputer atau jaringan komputer sebagai alat, atau sebagai sasaran, serta lokasi terjadinya kejahatan, tidak adanya batasan ruang dan waktu memudahkan penjahat cyber untuk melakukan aksinya di dunia cyber. Tujuan penulis melakukan analisis ini adalah untuk membahas apa saja yang menjadi kendala dalam menangani kasus cybercrime di saat masa pandemi Covid-19 dan bagaimana penegakan hukum bagi para pelaku cybercrime. Artikel ini meruupakan hasil dari penilitian hukum normatif yang fokus pada penggunaan data sekunder. Kejahatan cyber crime perlu mendapatkan perhatian khusus dari penegak hukum baik nasional maupun Internasional. Pelaku cybercrime belum seluruhnya dapat di proses hukum karena lemahnya sistem perundangan-undangan siber di Indonesia dan terbatasnya tenaga ahli yang dimilki untuk menangani kasus ini, Undang-Undang cyber belum dijabarkan dengan jelas didalam Peraturan yang mengatur mengenai teknis pelaksanaannya. Pelaku cyber crime berasal berbagai dari negara, terbatasnya SDM dan prsarana menjadi kendala utama. Diperlukan komitmen yang kuat dari pimpinan, Institusi penegak hukum untuk meningkatkan kualitas dan kuantitaf SDM serta penyiapan anggaran yang memadai untuk pengadaan sarana dan prasana serta menjalin kerjasama dengan pendidikan tinggi untuk mempercepat penanganan keterbatasan yang ada.
\end{abstract}

Kata kunci : cyber crime; penegakan hukum.

\section{PENDAHULUAN}

\section{Latar Belakang}

Meningkatnya pengguna Internet di saat situasi pandemi naik signifikan hal ini bukan tanpa sebab, Pemerintah mengeluarkan Peraturan No 21/2020 Tentang kebijakan PSBB, oleh sebab itu masyarakat dihimbau agar tetap di rumah dan menjalani seluruh kegiatan yang biasanya 
dilakukan secara langsung akan tetapi sekarang dilakukan secara daring dan hanya bergantung pada komunikasi dan informasi secara online, hal ini membuat masyarakat rentan menjadi korban kejahatan cyber. Berdasarkan data yang diperoleh kasus cyber crime mengalami peningkatan dari tahun 2017 (Januari-Oktober) terjadi 5.061 kasus .( Ambaranie Nadia kemala movinata,2017).Tahun 2018 terjadi 4630 kasus(Bhakti Eko Nugroho, M.A 2021 ). Tahun 2019 (Januari-Agustus) terjadi 3.429 kasus. Sedangkan tahun 2020 (Januari-medio Agustus) terjadi 2.599. tahun 2021 (April-Juli) terjadi 937 kasus Bhakti Eko Nugroho, M.A 2021). Saat ini Indonesia menduduki peringkat 9 dari total 47 negara yang di analisis menurut laporan media sosial Inggris, we are social yang diterbitkan pada 11 February 2021.(Conney stephanie,2021)

Menurut Bakti Eko Nugroho, Sekretaris dosen Kriminologi Fisip UI situasi pandemi telah menyebabkan sebagian masyarakat kehilangan pekerjaannya, yang menjadi salah satu faktor meningkatnya kriminalitas yang diantaranya cyber crime dengan modus yang makin beragam seperti meminta sumbangan, pencurian data, pembobolan rekening dengan target device, hardware, software juga data personal. Cyber crime sendiri sangat kompleks karena pelaku dan korban sangat invisible, anonimitas pelaku menyebabkan lebih mudah menyembunyikan identitas, ada jeda waktu untuk menghilangkan bahan bukti. Kasus tertinggi kasus provocative, hard content dan hate speech, penipuan online, konten porno(Bhakti Eko Nugroho, M.A 2021) selama pandemi terjadi kejahatan baru berupa menjual barang dan alat kesehatan jauh diatas normal, penimbunan barang, informasi hoax tentang pandemi. Pelaku cyber crime memanfaatkan mengambilkan keuntungan dari kerentanan dari ketidak berdayaan dan keterb atasan selama pandemi. (Bhakti Eko Nugroho, M.A 2021)

Pada cyber police tahun 2020 KA Bareskrim Polri menegaskan terjadinya peningkatan secara signifikan kegiatan cyber. Jenis kejahatan seperti "penipuan, pencemaran nama baik, ujaran kebencian, pornografi, dan penyebaran konten bermasalah", menjadi daftar urutan tertinggi dalam kasus cybercrime. Situasi pandemi telah mengubah masyarakat menjadi information sosiaty yang memungkinkan cyber crime.(Jpnn,2020)

Dengan demikian dimasa pandemi ini ancaman cyber crime meningkat dari tahun sebelumsebelumnya, dikarenakan masa pandemi banyak masyarakat memanfaatkan teknologi informasi secara online untuk memenuhi kebutuhannya, sehingga penjahat cyber memanfaatkan ketidakpahamanan masyarakat tentang bagaimana seharusnya menjaga privasi data diri mereka dalam pengguna teknologi informasi.

Saat masyarakat menghadapi kecemasan dan dilanda kekhawatiran yang berlebihan, akibat kabar yang simpang-siur tentang bahaya covid yang terus menerus hal ini dimanfaatkan para pelaku cybercrime untuk mejalankan aktivitasnya di dunia maya dan media sosial. Kasus cyber crime memerlukan pengawasan dan penanganan khusus dalam bidang teknologi informasi, karena kejahatan jenis ini tidak terpengaruh batas teritorial dan waktu.

Selama ini para pelaku cyber crime belum seluruhnya dapat di proses hukum sebagai akibat dari lemahnya sistem perundangan-undangan cyber di Indonesia, hal ini disebabkan karena peraturan cyber pelaksanaannya belum ada Peraturan yang mengatur tentang teknis pelaksanaannya, untuk sementara saat ini pelaku cyber dijerat oleh UU No. 11/2008 "Tentang ITE" Junto hukum pidana.

\section{Rumusan Masalah}

Merujuk paparan tersebut, dirumuskan permasalahan sebagai berikut:

1. Bagaimana Implementasi UU No.11/2008 Tentang Informasi Transaksi Elektronik sebagai sarana penegakkan hukum cyber crime pada masa pandemi?

2. Apa yang menjadi kendala penegakkan hukum terhadap cyber crime pada masa pandemi? 


\section{Tujuan Penelitian}

Berdasarkan sebagaimana yang telah terurai di latar belakang diatas, artikel ini akan melakukan analisis tentang bagaimana penegakan hukum terhadap para pelaku cybercrime dan apa saja kendala yang dihadapi oleh aparat penegak hukum untuk menyelesaikan kasus cyber crime pada masa pandemi covid-19 berdasarkan UU No.11/2008 Tentang Informasi Teknologi Elektronik

\section{METODE PENELITIAN}

Penelitian ini diteliti menggunakan hasil penelitian hukum normatif yang berfokus pada data sekunder/tidak langsung yang mencakup bahan hukum primer seperti UU ITE, KUHP serta bahan hukum sekunder yang memberi penjelasan terhadap bahan hukum primer yang mencakup berbagai literatur seperti buku, artikel, makalah, dan sebaginya, terkait dengan topik artikel ini maupun bahan hukum tersier yang memberi penjelasan bahan hukum primer dan bahan hukum sekunder yang mencakup kamus seperti KBBI. Penelitian yang dilaksanakan menggunakan pendekatan kualitatif untuk memahami gejala-gejala dengan didukung data kuantitatif dari berbagai pihak atau institusi. Seluruh data dikumpulkan dan klasifikasi menurut kelompoknya serta diolah dan dianalisis secara kualitatif dengan menggunakan logika deduktif.

\section{HASIL DAN PEMBAHASAN}

\section{Implementasi Undang-Undang Nomor 11 Tahun 2008}

Penegakan hukum terhadap cybercrime telah di amanatkan dalam peraturan perundangundangan yaitu :

UU No. 11/2008 "Tentang Informasi dan Transaksi Elektronik", disingkat UU ITE dan telah mengalami perubahan dengan UU No. 19 /2016. UU ITE dengan menentukan adanya ketentuan pidana berarti menentukan adanya perbuatan yang dilarang, dan oleh karena itu diancam dengan sanksi pidana. Adapun ketentuan tentang itu diatur dalam Pasal 45, Pasal 45 huruf a dan b, Pasal 47, Pasal 48, Pasal 49, Pasal 50. Berkenaan dengan itu terdapat pula ketentuan dengan pasal KUHP yang berkaitan dengan cybercrime yakni untuk kasus carding (Pasal 362 KUHP), penipuan (Pasal 378 KUHP), pengancaman dan pemerasan melalui e-mail (Pasal $335 \mathrm{KUHP}$ ), pencemaran nama baik (Pasal 331 KUHP), perjudian (Pasal 303 KUHP), pornografi (Pasal 228 KUHP), penyebaran foto dan video yang fulgar (Pasal 282 dan 311 KUHP). Disamping itu kasus cybercrime yang terjadi pada masa pandemi adalah peretasan yakni kejahatan dilakukan oleh penyusup dengan mengakses komputer tanpa izin seperti kasus peretasan situs Setkab beberapa tahun yang lalu, penggelapan uang bank, kasus hacking

Perlu diketahui bersama bahwa menurut Roscoe Pound hukum memiliki dua fungsi yaitu "as a tool of social control and as a tool of social engineering" maka dapat dikemukakan bahwa sejatinya UU ITE memuat berbagai ketentuan yang pelaksananya dapat mendorong upaya rekaya masyarakat dalam memahami dan melakukan pengendapan nilai nilai baru masyarakat modern yang pada situasi pandemi mengalami dan menjalani kehidupan sosial yang penuh dengan pembatasan sebagaimana telah ditetapkan pemerintah dalam kebijakan PPKM yang dengan itu masyarakat harus menerapkan menjaga jarak, memakai masker,mencuci tangan secara rutin, menghindari kerumunan,dan mengurangi mobilitas sementara secara kultural masyarakat Indonesia adalah masyarakat yang komunal yang kerap berkumpul untuk berbagai macam keperluan maupun beraktivitas guna menjalani suatu pekerjaan atau profesi tertentu.

Fakta menunjukan bahwa masyarakat kerap melanggar ketentuan $5 \mathrm{M}$ tersebut dengan berbagai dalih bahkan bertindak nekat tanpa menghiraukan keselamatan dan kesehatan dirinya keluarga dan lingkungan seperti memaksakan kehendak memakamkan sendiri jenazah kerabatnya yang positif Covid-19, menyelenggarakan resepsi perkawinan, melakukan ritual keagamaan, tetap bekerja tanpa mematuhi prokes, berwisata dan lain sebagainya. Memang bukan persoalan 
sederhana dan mudah mengubah persepsi sikap dan perilaku dalam waktu singkat apalagi dalam bayang-bayang resesi ekonomi

Sehubungan dengan hal tersebut, pemerintah perlu terus berupaya melakukan langkah-langkah persuasif, prefentif, dan edukatif dengan sesedikit mungkin melakukan tindakan represif kepada warga masyarakat yang sedang dilanda kebingungan, terkikisnya harapan yang menyertai pandemi covid-19 serta resesesi ekonomi yang telah meningkatkan jumlah pengangguran secara signifikan. Oleh karenanya pemerintah perlu lebih intensif menjalin koordinasi dan kemitraan dengan tokoh agama, tokoh masyarakat maupun kalangan Perguruan tinggi untuk mencari jalan keluar yang smooth sehingga kedamaian hidup dan equilibrium dapat terjaga juga sekaligus mencegah terjadinya eskalasi emosi kelompok-kelompok masyarakat yang pada giliranya dapat mengarah pada tindakan-tindakan destruktif yang mengganggu stabilitas kehidupan masyarakat Bagaimanapun juga berbagai kaidah hukum yang dimuat dalam berbagai peraturan perundangundangan maupun peraturan kebijakan harus memperhatikan nilai-nilai yang hidup dalam masyarakat bagaimana terdapat pada kaidah hukum agama/kepercayaan, kaidah kesusilaan/kesopanan, maupun Hukum Adat yang tidak tertulis sehingga seluruh kaidah yang ada memberi sinergi satu sama lain. Tidak pada tempatnya jika kaidah hukum yang terdapat dalam UU ITE di benturkan dengan kaidah sosial lainya.

\section{Kendala Penegakan Hukum Terhadap Cybercrime Pada Masa Pandemi}

Meskipun di Indonesia telah terdapat aturan aturan yang bisa menjerat para pelaku cybercrime, faktanya hal ini belum dijalankan secara maksimal hal ini masih bisa dijumpai adanya kendalakendala dalam penanganan kasus cyber crime, sebagai berikut :

Perangkat hukum yang ada saat ini oleh sebagian kalangan dianggap belum memadai. UU No. 11/2008 Tentang "Informasi dan Transaksi Elektronik" baru sebuah tameng bagi pengguna teknologi dan informatika dalam mencapai kepastian hukum. UU ITE sampai saat ini belum dibuat dalam proses pelaksanaannya. UU ITE masih bersifat abstrak, sehingga menimbulkan kesulitan pembuktian. UU ITE merupakan pengembangan tindak pidana khususnya dari KUHP, yang dikaitkan dengan perkembangan teknologi informasi sebagai alat atau instrumen dalam melakukan kejahatan. Pembuktian merupakan faktor yang sangat penting mengingat infrastruktur teknologi informasi belum sepenuhnya dapat terakomodir dalam sistem KUHP Indonesia, sehingga diharapkan ketentuan mengenai pemanfaatan teknologi informasi diatur secara tegas sehingga terdapat suatu kepastian.

Kurangnya pengawasan terhadap penggunaan internet menciptakan terjadinya kejahatan dunia maya. Kejahatan ini menggunakan akses internet yang tidak hanya terjadi dalam suatu wilayah. Keterbatasan Tenaga Ahli dalam melakukan penyelidikan menjadi faktor yang mempengaruhi keberhasilan aparat kepolisian dalam memberantas kasus cybercrime, dengan jumlah anggota ahli yang sangat minim menjadi batu hambatan dalam memberantas kasus kejahatan dunia maya yang tidak bisa diselesaikan dengan waktu yang efisien, sehingga hal tersebut dimanfaatkan oleh para pelaku dalam menjalankan aksinya dengan lebih leluasa.

Personil cyber police Indonesia hanya beranggotakan 58 anggota, tentunya angka tersebut tidak sepadan dengan laporan kasus yang masuk dalam catatan kepolisian tentang kejahatan dunia maya, keterbatasan jumlah personil sebetulnya bisa diatasi dengan cara melakukan kerjasama, baik oleh pihak kepolisian atau oleh pihak universitas dan perguran tinggi. Hal ini di perlukan untuk membuat tenaga-tenaga ahli dalam bidang teknologi informasi. Para tokoh publik juga berperan penting dalam memberikan masukan masukan kepada pemerintah dalam keamanan jaringan Internet.

Minimnya Tenaga ahli dalam bidang informasi dan teknologi juga harus di imbangi dengan adanya sarana prasarana yang memadai dalam menunjang keamanan jaringan dan juga untuk memudahkan pelacakan pelaku cyber crime dapat diatasi dengan cepat Kendala lain adalah 
terbatasnya anggaran oprasional yang kurang menjadi fakor signifikan dalam mengungkapkan kasus kejahatan siber, dengan keterbatasan anggaran berdampak langsung pada peralatan yang digunakan maupun minimnya biaya oprasional pihak kepolisian untuk mendeteksi pelaku cybercrime.

Terjadinya pandemi Covid-19 yang beriringan dengan resesi ekonomi telah menyebabkan telah menyebabkan makin menguatnya disiorentsi sosial, secara umum banyak anggota masyarakat kehilangan arah dalam memahami berbagai perubahan yang terjadi saat pandemi dan resesi banyak perusahaan menghentikan kegiatanya sehingga menambah jumlah pengangguran yang dapat memicu meningkatkan angka kejahatan. Sementara itu, orang-orang yang bekerja dari rumah (WFH) atau belajar dari rumah (SFH) menimbulkan permasalahan lanjutan. belum lagi soal keterbelahan masyarakat akibat pilkada dan pilpres yang terus mebayangi sebagian pendukung calon sehingga menimbulkan benturan dalam kehidupan bermasyarakat. Realitas menunjukan bahwa mantan pendukung calon hingga hari ini terus saja mengumbar rasa kebencian satu sama lain padahal Pilkada dan Pilpres sudah selesai cukup lama

Dari sudut pandang sikologi, manusia secara alamiah melakuan imitasi sikap dan perilaku orang tua guru dan tokoh-tokoh masyarakat dan sebagainya, sehingga berkembang budaya paternalistik dimana masyarakat cenderung meniru apa yang dilakukan oleh pemimpin, oleh karna itu masyarakat memerlukan pemimpin yang dapat menjadi role model. Dalam hal ini keluarga memiliki peran paling dasar untuk membimbing para anggota keluarganya, selain itu peranan lingkungan sekolah sangat seperti pribahasa "guru kencing berdiri,murid kencing berlari" hal tersebut berarti apa yang dilakukan oleh seorang akan ditiru oleh seorang muridnya, dengan demikian diperlukan pendidik yang lebih inters lagi dan kurikulum harus diselaraskan untuk menanamkan nilai nilai-nilai agar mereka siap menghadapi segala perubahan.

\section{KESIMPULAN DAN SARAN}

UU No.11/2008 Tentang ITE hanya baru sebuah payung bagi masyarakat pengguna teknologi dan informatika dalam mencapai kepastian hukum. Hingga saat ini belum ada sebuah Peraturan Pemerintah yang mengatur mengenai teknis pelaksanaannya. Pengaturan lebih lanjut UU No 11/2008 "Tentang Informasi dan Transaksi Elektronika" perlu segera diwujudkan sebagai upaya untuk memenuhi kebutuhan dan tuntutan masyarakat yang semakin mengglobal disamping sebagai langkah konkrit dalam rangka harmoni peraturan khususnya mengenai cyber crime.

Keterbatasan prasarana alat pendekteksi cyber disebabkan oleh minimnya dana yang dianggarkan menjadi kendala tersendiri disamping terbatasnya rasio personil di lingkungan polri yang menguasai teknologi informasi yang terus berkembang. Sementara masyarakat masih blum memahami sepenuhnya prosedur pelaporan dan rendahnya pemahaman tentang berbagai sisi keterbukaan informasi yang di perolah dari penggunaan alat komunikasi yang berbasis internet. Pemerintah se harus memberi pemahaman kepada masyarakat terhadap etika dan tanggung jawab dalam berinteraksi di dunia cyber. Perlu ada peningkatan kesadaran literasi masyarakat tentang keamanan cyber. Pemerintah harus membangun platfrom digital security di Indonesia. Institusi kepolisian perlu menjalin kolaborasi dengan pihak perguruan tinggi untuk meningkatkan kualitas penguasaan teknologi informasi melalui berbagai macam bentuk kemitraan yang berkelanjutan disamping mandapatkan SDM yang terdidik dan terlatih yang dapat mendukung penyelidikan cyber crime. selain itu juga pemerintah memerlukan kerja sama dengan berbagai negara dalam menangani kasus cybercrime untuk menelusuri para pelaku cybercrime 


\section{Ucapan Terima Kasih}

Bersama ini tim penulis menyampaikan terima kasih kepada keluarga dan rekan serta mata kuliah Pengantar Hukum kelas GZ di Fakultas Hukum Tarumanagara yang telah mendukung secara penuh sehingga tim penulis dapat menyelesaikan artikel sebelum batas waktu yang telah ditetapkan

\section{REFERENSI}

Arifah, D. A. (2011). kasus cyber crime di indonesia. vol.18 No.2 september 2011, 1-11.

jpnn.com. (2020, Juni 19). https://www.jpnn.com/. Retrieved from Jumlah Kejahatan Siber Meningkat Signifikan dalam Lima Tahun Terakhir: https://www.jpnn.com/news/jumlahkejahatan-siber-menin_gkat-signifikan-dalam-lima-tahun-terakhir

Kitab Undang-Undang Hukum Pidana (KUHP)

Kuncorojati, C. (2019, Oktober 29). https://www.medcom.id/. Retrieved from penipuan-menangundian-masih-jadi-kejahatan-siber-tertinggi: https://www.medcom.id/teknologi/newsteknologi/JKRV8Y7K-sms-penipuan-menang-undian-masih-jadi-kejahatan-siber-tertinggi

Media, B. L. (2021, Juli 16). https://fisip.ui.ac.id/. Retrieved from Cyber Crime Meningkat Tajam di Masa Pandemi: https://fisip.ui.ac.id/bhakti-cybercrime-menjadi-jenis-kejahatanyang-mengalami-peningkatan-cukup-tinggi/

Mediana. (2019, Maret 8). https://www.kompas.id. Retrieved from Ancaman Kejahatan Siber, Indonesia di Peringkat Ke-9: https://www.kompas.id/baca/utama/2019/03/08/ancamankejahatan-siber-indonesia-di-peringkat-ke-9/

Pahajow, A. A. (2016). Lex Crimen Vol. V/No. 2/Feb/201. PEMBUKTIAN TERHADAP KEJAHATAN DUNIA MAYA DAN UPAYA MENGATASINYA MENURUTHUKUM POSITIF INDONESIA, 1-9.

Peraturan Pemerintah Republik Indonesia Nomor 21 Tahun 2020 Tentang Pembatasan Sosial Bersekala Besar Dalam Rangka Percepatan Penangangan Corona Virus Disease (Covid19), (Lembaran Negara Republik Indonesia Tahu 2020 Nomor 91, Tambahan Lembaran Negara Republik Indonesia Nomor 6487)

Septanto, H. (2018). Kalbiscentia,Volume 5 No. 2 Agustus 2018. Pengaruh HOAX dan Ujaran Kebencian Sebuah Cyber Crime Dengan Teknologi Sederhana di Kehidupan, 1-6.

Supanto. (2016). Yustisia. Vol.5 No.1 Januari - April 2016. PERKEMBANGAN KEJAHATAN TEKNOLOGI INFORMASI (CYBER CRIME) DAN ANTISPASINYA DENGAN PENAL POLICY, 1-23

Stephanie, C. (2021, febuari 23). https://tekno.kompas.com/. Retrieved from Berapa Lama Orang Indonesia Akses Internet dan Medsos Setiap Hari?: https://tekno.kompas.com/read/2021/02/23/11320087/berapa-lama-orang-indonesia-aksesinternet-dan-medsos-setiap-hari-?page=all

Sukranatha, I. M. (2013). Vol. 01, No. 04, Juni 2013. 1KENDALA DALAM PENANGGULANGANCYBERCRIME SEBAGAI SUATU TINDAK PIDANA KHUSUS, 15.

Yuliani, A. (2018, Januari 5). https://www.kominfo.go.id/. Retrieved from Kenalan Dengan Cyber Drone 9, Polisi Internet Indonesia: https://www.kominfo.go.id/content/detail/12292/kenalan-dengan-cyber-drone-9-polisiinternet-indonesia/0/sorotan_medi

Yusran, A. W. (n.d.). TINJAUAN HUKUM TERHADAP CYBER CRIME DI INDONESIA. Undang-Undang Republik Indonesia No.11 Tahun 2008 Tentang Informasi dan Transaksi Elektronik. (Lembaran Negara Republik Indonesia Tahun 2008 Nomor 58, Tambahan Lembaran NegaraRepublik Indonesia Nomor 4843) 


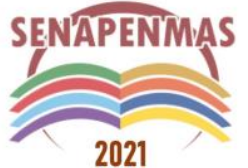

Seminar Nasional Hasil Penelitian dan Pengabdian Kepada Masyarakat 2021

Pengembangan Ekonomi Bangsa Melalui Inovasi Digital Hasil Penelitian dan Pengabdian Kepada Masyarakat Jakarta, 21 Oktober 2021

Undang-Undang Republik Indonesia No.19 Tahun 2016 Tentang Perubahan Atas UndangUndang No.11 Tahun 2008. (Lembaran Negara Republik Indonesia Tahun 2016 Nomor 251. Tambahan Lembaran Negara Republik Indonesia Nomor 5952)

Webinar FISIP U I $\underline{h}$ ttps://youtu.be/IKEbY62Y6qw 
Seminar Nasional Hasil Penelitian dan Pengabdian Kepada Masyarakat 2021

Pengembangan Ekonomi Bangsa Melalui Inovasi Digital Hasil Penelitian dan

Pengabdian Kepada Masyarakat

Jakarta, 21 Oktober 2021

(halaman kosong) 